\title{
Democracy Consolidation and Governance of the Security Sector in Nigeria: Trends and Challenges
}

\author{
Olusola Olawale Olasunkanmi \\ Afe Babalola University, Ado-Ekiti, Nigeria \\ P.M.B. 5454 \\ waleholusola@gmail.com \\ DOI: https://doi.org/10.32890/jis2016.12.9
}

\begin{abstract}
In no other sector is the challenge of governance much more tasking in contemporary Nigeria than security. Conceived broadly to imply both physical and human security, security has remained at the core of Nigeria's governance challenges since its return to democracy in 1999. Weak institutions, growing inequality, poverty, injustice and corruption have together undermined the capacity of democracy as a preferred system of rule, to salvage the nation's security from prolonged years of military rule and inept leadership. With Nigeria's almost two decades of democratic experience, and the recent ushering to power of another party, the first of this development since 1999, there is indeed, an urgent need for the overhaul of the sector if the expected gains of democracy are to be met. It is the contention of this paper that democracy and security are mutually reinforcing and a disconnect can have deleterious implications for Nigeria. This paper also stresses the need to revamp the country's security institutions especially in the light of the internal challenges of Boko Haram and in particular, militia groups whose propensity to relapse into military confrontation under the guise of the underlying historical problems associated with the Nigerian state are well documented.
\end{abstract}

Keywords: Democracy consolidation, security and governance.

\section{Introduction}

The Nigerian state, a British creation, wedging together diverse, multiple ethnic groups and identities, has historically evinced varying features of complexity since its birth in 1914 . Given this complex arrangement, the greatest threat to its security has always been itself. Upon independence, the responsibility for managing this diversity was bequeathed to a cream of leaders who were themselves not immune from the ethno-religious sentiments that incessantly threatened the corporate existence of Nigeria and exposed the fractured nature of the country's fragile composition. The task of nation-building was intermittently thwarted by frequent military incursions that characterized three decades of post-independence Nigerian politics. While those early years represented a vantage opportunity for the oilrich and most populous black nation on earth to engineer a political leadership that puts the 
people at the heart of governance, politics was rather driven by various forms and shades of unethical practices that promoted violence, injustice and corruption. By implication, neither the physical security nor basic human wants were within reach of a vastly growing national population.

In particular, Nigeria had never been to war with another country or entity and had hardly been faced with a serious external threat which showed the laxity with which the nation's authorities had handled national security matters until 1967 during the civil war. This was the first time Nigeria seriously felt threatened and this prompted a policy re-evaluation of its national security. Even the attack by Cameroon gendermes on Nigeria's security officers stationed along the once disputed Bakassi Peninsula did not draw a military retaliation from the country's leadership which preferred diplomacy above all else.

With the decades of oppression under successive military regimes terminated in 1999 and Nigeria's celebrated return to civil rule, expectations were high regarding the limitless opportunities that the emerging democratic climate in the country offers. This also coincided with the changing perception of security globally from the restricted view which solely identifies it with the military into a more holistic view which today, embraces also the essential task of meeting basic human wants. It is also contended that democracy and security are intertwined with the former having the capacity to help secure the objectives of the latter. However, a sore point in Nigeria's democratic experience in over a decade of civilian rule captures a catalogue of abuses, and unprofessional, partisan and anti-democratic practices championed by the state security against civilians on the one hand and a failure to translate the promises of democracy into concrete developments that free or attempt to free the citizenry from wants. Thus, in many ways, current realities largely reflect the imageries of the past. The inability to secure these basic needs among others has triggered the rise of militant groups whose permanence has continued to question Nigeria's approach to threats within its borders. But more fundamentally, it raises fundamental questions about the quality of Nigeria's democracy and its ability to reinforce national capacity in the pursuit of security goals.

\section{Democracy, Democratic Consolidation and Security Governance}

Democracy as a form of government aims primarily at guaranteeing political and socioeconomic rights and freedom. Democracy encourages participation, openness, and permits the exercise of individual choice as well as promotes institution building. Unlike a number of other regions, Africa's experience with liberal democracy took a significant upward path from the 1980s. Following many years under colonial and military rules, democracy became fashionable for Africa not because it was so desired but because first, it was a requirement for obtaining the desperately needed loans from the Brettonwood institutions. Secondly, by 1990 , it had no ideology competing with it following the collapse of the Soviet Union. Thirdly, the end of the Cold War exposed the fragility of many African countries which had been held together by aid support from the hitherto two dominant blocs and who had 
to adjust their political system to the dictates of the post-Cold War Order. Thus, African countries opted for a system they neither understood nor could understand or were ready to adapt to the peculiarities of their own traditional political practices. Current adaptations have only created worse forms of democracy through the legitimization of authoritarianism, dictatorship and patronage. For instance, only Ghana representing less than $2 \%$ of the 54 African countries qualifies as a full democracy while the others are either partially free or not free according to Freedom House (Freedom House, 2013, 2014 and 2015) ${ }^{1}$.

One central concern then lies in trying to understand the extent or degree to which democracy exists in a given country. In measuring democracy, there is the general (mis) understanding in some quarters, among educated and non-literates, that physical projects can be regarded as the dividends of democracy. However, democratic dividends are not just about visible, tangible projects but about the rights to enjoy fundamental elements of liberty, openness and participation, which inadvertently translate into a variety of opportunities for the individual. Also, a fundamental feature of liberal democracy is the people power, expressed through the conduct of and participation in elections, to determine who governs them. Therefore, countries that have institutionalized this within their political framework are considered democracies or more specifically, electoral democracies. The excessive emphasis on electoral democracy has come almost at the expense of real democracy which rather offers more in terms of substance than name. These dichotomies have given rise to democracy under different guises and labels such as authoritarian democracies, pretend democracies, etc. Though fundamental, electoral decision-making is but one of the many rights that democracy promises.

Table 1

Democracy Index $2010-2015$

\begin{tabular}{ccccc}
\hline Year & Rank & Score & Total & Regime Categorization \\
\hline 2010 & 123 & 3.47 & 167 & Authoritarian \\
2011 & 119 & 3.83 & 167 & Authoritarian \\
2012 & $\mathrm{~N} / \mathrm{P}$ & $\mathrm{N} / \mathrm{P}$ & $\mathrm{N} / \mathrm{P}$ & N/P \\
2013 & 121 & 3.77 & 167 & Authoritarian \\
2014 & $=123$ & 3.76 & 167 & Authoritarian \\
2015 & 108 & 4.62 & 167 & Hybrid \\
\hline
\end{tabular}

Source: The Economist Intelligence Unit

On the other hand, democratic consolidation is about consistent and sustained practice of democratic principles (Yagboyaju, 2013). ${ }^{2}$ For Asiwaju (2000), democratic consolidation "implies the internationalization of democratic culture and the institutionalization of democratic "best practices" by a polity that has successfully embarked on a democratic transition". ${ }^{3}$ It is about conduct, philosophy and ideas that promote democratic tenets. It may also be inclusive of efforts or struggles to liberalize a democracy that is already in place. 
It includes institutional changes that expand socio-economic and political opportunities for all peoples irrespective of sex, economic status or age. When democratic processes, principles and practices are preserved, or improved upon, then democracy is being nurtured into a state of maturity. Democracy consolidation presupposes that there is democracy in place which is being consolidated. It also assumes that every democracy takes a path of consolidation perhaps due to the fact that every system, in time and space, evolves through its own particularities and the changing conditions which may be domestic and/or external. Two points are notable, first, the quality of democracy varies and electoral democracies that have sustained records of abuse and violations of fundamental rights and dignity of citizens, or lost the capacity to oversee borders such as in Somalia or where citizen voices have been profoundly suppressed cannot be said to be consolidating.

Democracy continues to shape how we think about the world and how best to respond to new threats and the growing needs of humanity. The nexus between democracy and security has been well established. In particular, the re-conceptualization of security from its traditional fixation on the state to the individual represents an important shift in the attempt to understand the complex nature of modern society and its accompanying challenges. Security is today understood to mean freedom from a wide range of threats such as wants, poverty and rights violations. According to the Human Development Report 1994, the concept of security has changed from one focused on nations, arms, and territory to a greater concern with people, human development, food, employment, and the environment (Human Development Report, 1994). ${ }^{4}$ The Human Security Report 2003, also defined security as being linked to the enhancement of the livelihood of all people at risk; the values of the respect of human rights; dignity of the individual, respect for diversity, community empowerment, decentralized forms of government, peace and co-existence, and the accountability and transparency of actions aimed at creating betterment of livelihood (Human Security Report, 2003)..$^{5}$ In a sense, these ideas and arguments are part of the efforts at projecting democracy's inherent capacity to effectively secure the goals of security in a contemporary international system.

Furthermore, relevant actors within the security sector include all those organizations that have the authority to use, or order the use of, force or threat of force, to protect the state and its citizens, as well as those civil structures that are responsible for their management and oversight (Chalmers, 2000). ${ }^{6}$ The OECD DAC Guidelines on Security System and Governance Reform define the broader security system as "which includes all the actors, their roles, responsibilities and actions - working together to manage and operate the system in a manner that is more consistent with democratic norms and sound principles of good governance, and thus contributes to a well-functioning security framework' and consists of the core security actors; security management and oversight bodies: the executive; justice and law enforcement institutions; and non-statutory security forces (OECD, 2004). ${ }^{7}$ Summarily, democratic governance of the security sector must exhibit: accountability and transparency; existence of avenues for seeking redress; legitimacy; voice and participation of the civil society and professionals. More comprehensive criteria are offered by Ball 
et al. which include high priority to human rights protection, high public awareness and engagement, and regional approaches to security problems (Ball, \& Fayemi, 2004). ${ }^{8}$

Hutchful (2003) observed that the current liberal order reinforces the linkage between security and democracy. For him, policy choices made about the management and control of the military and security forces have significant implications for democratic consolidation, conflict prevention and the quest for sustainable peace. Apart from democracy helping to secure security objectives, democratic consolidation is difficult, if not impossible, in an atmosphere of insecurity. ${ }^{9}$ Corroborating this viewpoint, Ball et al. stressed that effective governance of the security sector is central to achieving successful democratic consolidation and sustainable economic and social development (Ball et al., 2003). ${ }^{10}$ Therefore, at the core of the security sector, governance must be the promotion and respect for human rights and the rule of law as well as the monitoring of the security sector policy by a well-informed, vibrant and independent civil society sector. Insecurity arises as a result of exclusion, injustice, lack of access to power and resources. Democracy, on the other hand, is a veritable instrument in adjusting this socio-economic and political imbalance which aims at empowering citizens to exercise critical rights to engender anticipated developmental outcomes.

Similarly, reform of the security sector helps consolidate good, responsible, and accountable governance. However, security sector reform without accompanying political and social reforms may defeat the purpose of reform. According to Hendrickson and Karkoszka, strengthening the institutional framework for managing the security sector involves three broad challenges: (a) to ensure the proper location of security activities within a constitutional framework defined by law, and to develop security policies and instruments to implement them; (b) to build the capacity of policy-makers to assess the nature of security threats effectively and (c) to design strategic responses supportive of wider development goals; and to strengthen mechanisms for ensuring security sector accountability by enabling the state and non-state actors responsible for monitoring security policy and enforcing the law to fulfil their functions effectively (Hendrickson and Karkoszka, 2005). ${ }^{11}$

\section{The Security Environment in Nigeria: A Synopsis}

The security sector in Nigeria is managed by a variety of actors whose contributions are not only critical but have impacted on the nature and character of the country's security apparatus. Nigeria's security architecture consists of five categories of actors which are tabulated below. Each category of actors plays important roles in the fulfillment of national security objectives. More importantly, the idea of checks and balances among the highlighted institutions and in particular, the watchdog role by civil society organizations remain essential to the delivery of security services that meet both state and individual needs. Since Nigeria's return to civil rule in 1999, efforts have been made by successive administrations via constitutional processes to re-define the roles, responsibilities and powers of old and new governance institutions to reflect democratic principles and ethos. 


\begin{tabular}{|c|c|c|c|c|}
\hline $\begin{array}{l}\text { Primary Security } \\
\text { Actors }\end{array}$ & $\begin{array}{l}\text { Justice and Law } \\
\text { Enforcement } \\
\text { Organizations } \\
\end{array}$ & $\begin{array}{l}\text { Security } \\
\text { Management and } \\
\text { Oversight Bodies }\end{array}$ & $\begin{array}{l}\text { Non -Statutory } \\
\text { Security } \\
\text { Organizations } \\
\end{array}$ & $\begin{array}{l}\text { Civil Society } \\
\text { Organizations }\end{array}$ \\
\hline $\begin{array}{l}\text { Armed Forces (army, } \\
\text { navy and airforce; } \\
\text { police; gendarmeries; } \\
\text { paramilitary } \\
\text { forces; presidential } \\
\text { guards; intelligence } \\
\text { and security services } \\
\text { (both military and } \\
\text { civilian); coast guards; } \\
\text { customs authorities; } \\
\text { and reserve or local } \\
\text { security units, civil } \\
\text { defense forces, } \\
\text { national guards, } \\
\text { militias). }\end{array}$ & $\begin{array}{l}\text { The judiciary, justice } \\
\text { ministries, } \\
\text { prisons; criminal } \\
\text { investigation and } \\
\text { persecution services; } \\
\text { human rights } \\
\text { commissions and } \\
\text { ombudsmen; and } \\
\text { customary and } \\
\text { traditional justice } \\
\text { systems }\end{array}$ & $\begin{array}{l}\text { The executive; } \\
\text { national } \\
\text { security advisory } \\
\text { bodies; legislature } \\
\text { and legislative } \\
\text { select committees; } \\
\text { ministries } \\
\text { of defense, internal } \\
\text { affairs and foreign } \\
\text { affairs; customary } \\
\text { and traditional } \\
\text { authorities; } \\
\text { and financial } \\
\text { management bodies } \\
\text { (finance, audit and } \\
\text { planning units). }\end{array}$ & $\begin{array}{l}\text { Liberation } \\
\text { armies, guerilla } \\
\text { armies, private } \\
\text { body guard units; } \\
\text { private security } \\
\text { companies; and } \\
\text { political party } \\
\text { militias }\end{array}$ & $\begin{array}{l}\text { Civilian review } \\
\text { boards and public } \\
\text { complaints } \\
\text { commissions, } \\
\text { professional } \\
\text { associations and } \\
\text { trade unions }\end{array}$ \\
\hline
\end{tabular}

Adapted from the Organization for Economic Cooperation and Development-Development Assistance Committee (OECD DAC) Guidelines on Security System and Governance Reform (2005); and Fayemi, J. K. (2008)

As succinctly expressed by Fayemi amd Olonisakin (2008), pivotal to security reform is the understanding that security of both the state and its population will be maximized to the extent that security organizations are subordinate to democratically-elected authorities (Fayemi and Olonisakin, 2008). ${ }^{12}$ Thus, one of the principal changes to the security sector was witnessed under President Olusegun who undertook some steps to subject the state's security structures to executive, legislative and judicial control. Although, similar actions have been sustained over the years to strengthen Nigeria's security system, the country's national security scorecard remains abysmal due to institutionalized military orientation, parochial interests, partisanship, and constitutional and institutional weaknesses. For instance, the inherited constitution accedes too much power to the presidents who in characteristic fashion, have consistently employed the same for nefarious uses during elections against political opponents and for showmanship. This has inadvertently left the country in more precarious situations given the competing ethno-religious and monetary interests of the political class.

In 2014, Nigeria was reported to have the unenviable record of nine (9) of the twenty (20) most fatal terrorist attacks. Alongside Iraq, both countries were responsible for $53 \%$ terrorism related deaths in 2014 (Global Terrorism Index, 2015: 13-14). ${ }^{13}$ Between 2000 and 2014, Nigeria has been ranked six times in the ten countries most affected by terrorism. Within the same period, the Boko haram was responsible for most deaths in Nigeria followed by the Fulani herdsmen (Ibid:15). ${ }^{14}$ From 2014 to 2015, Nigeria is believed to be among the countries to have deteriorated the most under the failed states index mapping (Fragile States Index, 2015:12). ${ }^{15}$ Arising from these numerous insurgency attacks was a massive human 
displacement which stood at 1.8 million Internally Displaced Persons (IDPs) and 201, 591 refugees as on April 30, 2016 (UNHCR, 2016). ${ }^{16}$ The implications of this development cannot be over-emphasized especially when considered in the light of Nigeria's status and demography; and the notoriety of the sub-regions security and stability problems. As a further consequence, the 2015/16 Global Competitiveness Index ranks Nigeria 124 out of 140 countries assessed, a marginal improvement from the 127 it was ranked in the 2014/15 survey (World Economic Forum, 2015-2016) ${ }^{17}$, while it ranked 170 and 169 out of 189 countries examined for ease of doing business in the 2015 and 2016 reports together, reflecting the deleterious impact of the appalling security situation in Nigeria (Doing Business, 2015, 2016: 4 \& 5). ${ }^{18}$

Table 2

Impact of Terrorism: First Five Most Affected Countries

\begin{tabular}{cccccccc}
\hline \multicolumn{2}{c}{ Global Terrorism Index } & Score & Score & \multicolumn{2}{c}{ Fragile States Index (2015) } \\
Rank (2015) & Rank (2014) & Countries & $\mathbf{( 2 0 1 5 )}$ & $\mathbf{( 2 0 1 4 )}$ & Countries & Rank & Classification \\
\hline 1 & 1 & Iraq & 10 & 10 & Syria & $=8$ & High Alert \\
2 & 2 & Afghanistan & 9.233 & 9.39 & Afghanistan & $=8$ & High Alert \\
$\mathbf{3}$ & $\mathbf{4}$ & Nigeria & $\mathbf{9 . 2 1 3}$ & $\mathbf{9 . 3 7}$ & Iraq & $=11$ & High Alert \\
4 & 3 & Pakistan & 9.065 & 8.58 & Pakistan & 13 & High Alert \\
5 & 5 & Syria & 8.108 & 8.12 & Nigeria & $\mathbf{1 4}$ & High Alert \\
\hline
\end{tabular}

Global Terrorism Index 2014, 2015.

These statistics lend strong credence to the state of security in Nigeria vis-à-vis the quality of governance. The current situation is not entirely new and has its roots in the permissive security environment created by years of inept leadership. Indeed, the history of Nigeria's security environment is not significantly different from what happened in most parts of Africa from the colonial to the post-colonial periods. Security has hardly been used to serve the interests of the people. Prior to 1999, Nigeria had spent much of its independence under military regimes thereby, leaving no room for democracy to take roots. Typically, the Nigerian state operated with brute force in the management of its internal affairs as security structure was either used to witch-hunt dissident voices or to protect or unseat one regime after another. Put differently, security objectives were not aimed at securing essential human wants but for the preservation of the regime. As observed by one author, the attempts by successive leaders to appeal to national, ethnic, communal and religious loyalties weakened the solidarity of the people, created strong divisions and exclusivity which increased the premium on political power and the intensity of political competition. Indeed, the military rule in Nigeria was characterized by impunity, virtual disrespect for the constitution as an instrument for safeguarding citizens' interests and rights, visionless and purposeless leadership, and waste and considerable acts of repression. All of these created a psyche of fear and despondency among the Nigerians and persisted under democratic administrations since 1999. 
Also, given the prolonged years under military rule, existing institutions still largely reflected the principles and practices of the old order. In other words, democratic transition was not accompanied by a fundamental change in the institutions of the state. The military's influence continues to define the country's political order. Several actions and reactions by the new leadership also revealed its intolerance to democratic ethos. The indiscriminate reprisal attacks on the Odi community in Bayelsa and Zaki-Biam in Benue state by the Nigerian military are reference of the points Human Rights Watch World Report, 2000 \& 2001). ${ }^{19}$ Journalists were arrested on trump charges and harassed as was the case during the military years. The penchant of the civilian administration for responding with force to civil matters indicated that the country still had a long way to go.

Also, the Nigerian security environment has been characterized by violence arising from cut cutthroat competitions during elections. While the successful transition from civilian to civilian administrations remains a positive development in Nigeria's democratization process, virtually every election has resulted in large scale violence due to the desperation of officeseekers who see political posts as access to the state treasury. Election results also largely reveal voting patterns that reinforce ethnicity as a strong determining factor in preference of electorates. Within political parties and during elections proper, violence continues to mar the conduct of elections in a manner that partly account for the marginalization of women in Nigerian politics. The 2007 elections were so rigged that it was described as the worst in the country's history. The 2011 elections, on the other hand, witnessed state-wide violence that almost threatened the survival of the Nigerian state.

In addition, no other development adequately captures Nigeria's security environment like the rise of ethnic militias such as the Bakassi boys, the Egbesu boys, Oodua Peoples Congress (OPC), Movement for the Actualization of the State of Biafra (MASSOB) and more recently, Boko Haram and the Niger Delta Avengers. Considerable debates exist on whether democracy inherently promotes violence. According to Abdu Hussaini, while recurring violence under democratic rule may be attributable to poor governance and leadership, the tendency to associate democracy with violence can be better understood when considered in the light of the freedom it bestows on the hitherto suppressed voices, identities and discontents. Thus, despite the return to civil rule, cries of marginalization and injustice continue to radicalize the Niger Delta as different groups emerge to stake claims on behalf of the region. The emergence of Boko haram, one of the deadliest insurgent groups globally, is also traceable to acts of injustice by the state against the members of the sect, in particular, the unexplained circumstances under which the sect's leader, Mohammed Yusuf, died and the inability of the relevant authorities to swiftly bring the alleged culprits to book. Fundamentally, all of these groups have been sustained in one form of the other due to a patronage system.

Of all Nigerian institutions, the Nigerian Police Force has been the most vilified national institution due largely to their penchant for corruption. For many Nigerians, the black uniform adorned by police officers is in every way synonymous with greed, injustice, 
bad omen and repression. The NPF may find no competitor for the position of the most corrupt institution in Nigeria, except perhaps second only to the Civil Service. Several cases of abuses are perpetuated by this important institution supposedly saddled with the responsibility to protect lives and civil order. Experiences indicate that they perform exactly the opposite. Indeed, one must be quick to add that the institution has also suffered years of neglect by the executive. Policemen in Nigeria are generally underpaid and the majority of them do not appear to have the wherewithal for a modest life. Indeed, they were prime targets for Boko Haram insurgents for many years. It is argued here that this was so because of the insurgents' awareness of the inherent weaknesses of the institution.

Table 3

The Fifteen Most Vulnerable Countries 2012, 2013 and 2014

\begin{tabular}{clcclcclc}
\hline Rank & Country (2013) & Score & Rank & Country (2013) & Score & Rank & Countries & Score \\
\hline 1 & Eritrea & 75.35 & 1 & Afghanistan & 75.41 & 1 & Chad & 75.72 \\
2 & Niger & 75.17 & 2 & Chad & 74.28 & 2 & Haiti & 73.79 \\
3 & Chad & 74.74 & 3 & Eritrea & 74.23 & 3 & Afghanistan & 73.73 \\
4 & Afghanistan & 74.32 & 4 & Niger & 73.21 & 4 & Eritrea & 73.18 \\
5 & Haiti & 73.54 & 5 & Haiti & 73.05 & 5 & Central African & 72.22 \\
& & & & & & Republic & \\
6 & Sierra Leone & 72.20 & 6 & Sierra Leone & 70.75 & 6 & Niger & 72.12 \\
7 & Liberia & 71.74 & 7 & Liberia & 70.31 & 7 & Sierra-Leone & 72.10 \\
8 & Mozambique & 71.37 & 8 & Central African & 69.98 & 8 & Liberia & 72.03 \\
& & & & Republic & & & & \\
9 & Guinea & 71.05 & 9 & Mozambique & 69.85 & 9 & Guinea & 70.94 \\
10 & Central African & 70.69 & 10 & Guinea & 69.21 & 10 & Mozambique & 70.89 \\
& Republic & & & & & & & \\
11 & Ethiopia & 70.21 & 11 & Madagascar & 69.18 & 11 & Mali & 70.53 \\
12 & Mali & 69.76 & 12 & Burundi & 69.17 & 12 & Burundi & 70.00 \\
13 & Burundi & 69.32 & $\mathbf{1 3}$ & Nigeria & $\mathbf{6 8 . 9 9}$ & 13 & Guinea-Bissau & $\mathbf{6 9 . 9 4}$ \\
$\mathbf{1 4}$ & Nigeria & $\mathbf{6 8 . 7 0}$ & 14 & Mali & 68.90 & 14 & Madagascar & 69.86 \\
15 & Togo & 68.39 & 15 & Comoros & 68.56 & $\mathbf{1 5}$ & Nigeria & 69.33 \\
\hline
\end{tabular}

Source: World Risk Report, 2012.

Again, from 2003 to date, records of using the military to harass and intimidate opposition members and their supporters by the ruling party have been widespread in Nigeria. In the recently concluded elections in Ekiti state in 2014, the tribunal while dismissing the opposition's case against the declared winner admitted credible evidence of the use of the military to ill-treat members of the opposition. Also, prior to the 2015 general elections, the court delivered a verdict declaring that the military had no business with elections as it is purely a civilian affair. Notwithstanding the judgment, the army was deployed in their numbers for the election. The flipside of these actions was the politicization of the 
military institution to aid and abet their paymaster's political ambition with inherently grave implications for the country's democracy.

\section{Assessing Security Sector Reforms and National Security Strategies in Nigeria}

A national security framework is central to effective, long-term security sector transformation. National security can be conceptualized at both state and individual levels. At the state level, security implies the preservation and protection of the territorial integrity against threats to national sovereignty. Individual security, on the other hand, revolves around vital interests such as job security, social security and security against natural disaster. Against this background therefore, the concept of security within a country's policy guide should encapsulate the new shift in understanding security. This alongside growing security threats perhaps informed the establishment of a new national security strategy in 2014 under the Jonathan administration (Premium Times, 2015). ${ }^{20}$

As noted earlier, security is inextricably linked to human development which covers the political, economic and social opportunities accessible to the citizenry. According to the Human Development Report (1994), social security, food security and environmental security are essential dimensions of human security (Human Development Report, 1994). ${ }^{21}$ Also, the French White Paper on Defence and National Security, noted that a NSP or strategy should deliver response to "all the risks and threats which could endanger the life of the Nation" (French White Paper on Defence and National Security, 2007). ${ }^{22}$ Therefore, a comprehensive and compliant NSP recognizes all sources of threat as well as contributions from all security sectors within the state including governmental and non-governmental actors, such that it allows for broad ownership of the policy. By so doing, it intricately establishes a link to peace, security and stability of the state. This is the more important given the changing nature of insecurity, the multiplicity of actors and the effect of globalization. The assurance of these basic securities complements state stability and security.

Table 4

Human Development Report Index: Nigeria 2010 - 2014

\begin{tabular}{|ccc|}
\hline Year & Rank (Total countries assessed) & Categorization \\
\hline 2010 & $142(169)$ & Low Human Development \\
2011 & $156(187)$ & Low Human Development \\
2012 & $153(172)$ & Low Human Development \\
2013 & $152(187)$ & Low Human Development \\
2014 & $152(188)$ & Low Human development \\
\hline
\end{tabular}

United Nations Development Programme (UNDP) Available at http://hdr.undp.org

Given the new political climate heralded by democracy, and the emergence of threats by non- state groups such as the Boko Haram sect, re-assessing the character of the country's 
security became among others, paramount. In 2014, faced with the menace of Boko Haram, the Jonathan administration prepared what is considered the first comprehensive national security strategy after deliberations among key security agencies, government institutions and civil society organizations. The strategy codified in three different documents centres around three fundamental strategies of National Security, Counter Terrorism and Cyber Security.

The intent of the strategy was to guide, organize, coordinate and harmonize Nigeria's security and efforts. According to the President, it demands multi-sectoral, domestic and international approaches, efforts and cooperation and would be subjected to review every five to ten years depending on the circumstance. The National Counter Terrorism Strategy, NACTEST is aimed at achieving a number of objectives which include preventing persons from joining or supporting terrorist groups; strengthening protection capacity against terror attacks; identifying threats through detection, early warning system and appropriate investigation of terrorist acts; mitigating the impact of terrorist attacks by building resilience; and implementing a framework for the mobilization of cross-governmental efforts. On the other hand, the National Cyber Security aims at mitigating the country's cyber risk exposure and curtailing cyber threats inimical to the national security and the economic wellbeing of the Nigerians. Like the NACTEST, it is guided by stated doctrines and principles for achieving set objectives via coordinated efforts of all partners in the country (Premium Times, 2015). ${ }^{23}$

Without doubt, the new strategy represents a landmark progress in the redefinition of security approaches to existing threats in Nigeria. Despite the sensitivity of the security issues, it is also noteworthy that wide consultations were made which ultimately produced the final documents. Indeed, certain provisions of the documents speak about the socio-economic and structural conditions underlying the growth of insurgent groups in many developing countries and in particular, Nigeria. The high rate of unemployment and economic insecurity have provided the opportunity for easy recruitment into terrorist formations. This socioeconomic deficiency narrative also expresses the situation in many weak states that have been projected to fail. The centrality of social and economic security to the security of the states absolutely necessitates its inclusion in the national security policy formulation and implementations.

Table 5

The State of Peace in the World: Nigeria

\begin{tabular}{ccccc}
\hline Year & Score & Sub-Saharan African ranking (Total) & World ranking (Total) & Classification \\
\hline $\mathbf{2 0 1 6}$ & 2.877 & $40(44)$ & $149(163)$ & Very Low \\
$\mathbf{2 0 1 4}$ & 2.71 & $40(44)$ & $151(162)$ & Low \\
$\mathbf{2 0 1 3}$ & 2.693 & $39(44)$ & $148(162)$ & Low \\
\hline & & & continued
\end{tabular}




\begin{tabular}{ccccc}
\hline Year & Score & Sub-Saharan African ranking (Total) & World ranking (Total) & Classification \\
\hline $\mathbf{2 0 1 2}$ & 2.801 & $39(43)$ & $146(158)$ & Low \\
$\mathbf{2 0 1 1}$ & 2.743 & $34(38)$ & $142(153)$ & Low \\
\hline
\end{tabular}

Global Peace Index

However, the swiftness in drafting the document is symptomantic of the general malaise that characterizes the Nigerian political leadership. The initiative seemed a forced reaction to the deteriorating security situation occasioned by mindless attacks by the Boko Haram sect rather than a proactive endeavour. Moreover, it is not clear if the new strategy contributed in any meaningful way to check the threat posed by Boko Haram or whether there is a monitoring mechanism to ensure that the guiding principles are dutifully observed. It is not also known if the current administration under President Mohammadu Buhari would be particularly interested given the circumstances that surround his own emergence and the instituted corruption cases against the erstwhile National Security Adviser and certain members of the ousted party.

Table 6

The 15 Countries with the Highest Lack of Adaptive Capacities Worldwide, 2013-2014

\begin{tabular}{cccccc}
\hline Rank & Country 2013 & $\begin{array}{c}\text { Lack of Adaptive } \\
\text { Capacities }\end{array}$ & Rank & Country 2014 & $\begin{array}{c}\text { Lack of Adaptive } \\
\text { Capacities }\end{array}$ \\
\hline 1 & Afghanistan & 76.11 & 1 & Afghanistan & 93.37 \\
2 & Eritrea & 72.57 & 2 & Sudan & 93.05 \\
3 & Niger & 71.76 & 3 & Chad & 91.88 \\
4 & Mali & 69.25 & 4 & Haiti & 91.04 \\
5 & Haiti & 67.88 & 5 & Yemen & 91.03 \\
6 & Chad & 67.61 & 6 & Guinea-Bissau & 89.71 \\
7 & Pakistan & 65.94 & 7 & Iraq & 89.30 \\
8 & Sierra Leone & 65.82 & 8 & Guinea & 89.29 \\
9 & Mauritania & 64.86 & 9 & Zimbabwe & 89.19 \\
10 & Burkina Faso & 64.44 & 10 & Central African Republic & 89.14 \\
11 & Guinea & 63.88 & 11 & Eritrea & 88.67 \\
12 & Benin & 63.54 & $\mathbf{1 2}$ & Nigeria & $\mathbf{8 8 . 0 6}$ \\
13 & Liberia & 63.28 & 13 & Uganda & 87.68 \\
$\mathbf{1 4}$ & Nigeria & $\mathbf{6 3 . 0 7}$ & 14 & Burundi & 87.62 \\
15 & Comoros & 63.00 & 15 & Cote d'ivoire & 87.56 \\
\hline
\end{tabular}

\section{Democracy Consolidation and Challenges to Security Sector Reform in Nigeria}

A major challenge confronting the Nigerian state in addressing the security sector problem is the lack of vision. For instance, since independence to date, no Nigerian leader was ever prepared to take the mantle of leadership. No genuine clear vision and strategy are 
articulated in addressing national challenges. In situations where the vision exists, political will is lacking. And where there is political will, past military leaders, couched in civilian garb arrogate the management of the country's security to themselves being once themselves in the force and therefore not open to inputs from other relevant actors. Even under civilian rule, no conscious effort is made to involve relevant stakeholders in a manner that ensures the sustainability of such actions or policies. A corollary to this is the fact that Nigeria has not completely extricated itself from military entanglement. Aside from Presidents Yar Adua and Goodluck Jonathan, President Obasanjo, a former military leader was in the saddle for eight years. Consequently, they adopted the fire brigade approach that window dresses the problems without addressing the root causes.

Another challenge revolves around the exercise of oversight functions by respective institution chiefs among which is the National Assembly. Apart from the routine duty of confirming appointments and establishing committees to oversee the affairs of various security sectors in Nigeria, much of the Assembly's activities are already predetermined by the ruling party. In essence, the recourse to promoting the 'one-party' state has impacted on policy direction and formulation. The effectiveness of oversight and monitoring is very much in doubt. For instance, the request for additional funds by the defence ministry in late 2014 to facilitate the combat against Boko Haram was questioned by the then opposition party on the claims that they could not account for the billions of dollars that were hitherto allocated for the same purpose (The Punch, 2014). ${ }^{24}$ This was more worrisome because no concrete progress was being made at the time against Boko Haram. In another vein, widespread corruption within the various government institutions has tended to undermine the nation's capacity to fairly and openly respond to pressing national security issues.

Again, while civil societies have done creditably well, they do not seem to have done enough to galvanize and stimulate the interests of the general public about the security sector. Civil societies have important roles to play in this regard by serving as agents or purveyors of knowledge that encourage the public to engage productively in the policy-making process. Most CSOs seem uninterested in security sectors matters, at least, relative to other spheres. Democracy affords the country the platform to inspire discourses that educate the public on the critical link between development and security such that accountability and integrity are ensured by all and sundry. Despite the passage of the Freedom of Information (FoI) bill which further strengthens the role of the CSOs as watchdogs over government's activities, it is yet to be fully taken advantage of.

Funding is a vital component of security sector reform and its sustenance over the long term. With the current state of the security sector in Nigeria, reform aimed at democratizing and improving its capacity to deliver will require staggering funds. Given the new conceptualization of security, funding the security apparatus should not come at the expense of other equally important institutions. Nigeria, like many other African countries, has been wary of partnering with countries like France, Britain, and the United States due to a number of factors some of which include the fear of political interference, the French 
factor in the sub-region, covetousness of its oil resource but mostly because of the westernoriented prescriptions that do not take into cognizance local and regional contexts. Even then, allocating huge sums for security at the expense of other socio-economic needs (as was the case in the 2014 national budget) that could help address the fundamental causes not only gives birth to insecurity but sustaining them may be counterproductive.

Similarly, there are usually cabals within the state with vested interests who may work to sabotage the effort at restructuring Nigeria's security sector. Indeed, the country is not a stranger to activities in this regard. There are certain elements who profit from the current malaise and who would naturally oppose or resist the change through mainly indirect channels. They may even work with foreign elements to frustrate the initiative and ensure that the status quo is preserved. The practice of appealing to ethnic sentiments and romanticizing poverty by political leaders has been evident in Nigeria's political culture. This in turn has affected citizens' perceptions of democracy and its dividends, thereby making it the onerous task of enhancing national values that promote integration and cohesion more difficult.

In addition, a major challenge, as with many other institutions in Nigeria, is corruption. Across the security sectors, corruption has eaten deep into the structures. It is a hydra-headed problem that must be confronted if the reform is to be acceptable to the public. The challenge is even more daunting given the length of decay and unhealthy practices that have long held these institutions bound. It would require a comprehensive legal and political commitment to ensure a credible reform. At the regional level, attempt is being made by the Economic Community of West African States (ECOWAS) for a policy guide for countries to support the reform of the security sector. While Nigeria is a key member of the community, it has had difficulties in the past over ECOWAS' integration policy such as the Free Protocol on Movement of Goods and Persons. Nigeria may face similar challenges since the underlying objective of the community's policies is to promote integration. Therefore, any regional policy that cannot be adapted to internal context may be counterproductive towards any genuine efforts at reforming the sector.

\section{Deepening Democratic Ethos and Enhancing Security Management in Nigeria}

At the heart of genuine democratic consolidation must be the individual and state promotion of the abiding principles of openness, participation and rule of law among others. The degree to which this is the case in Nigeria today is open to debate. Nigeria's sixteen year experience with democracy has yet to empower the citizenry in a manner they can take ownership of critical policies and programmes that affect the nation's well-being. People are yet to occupy a central place in governance despite electoral improvements. Beyond citizen's engagement, this paper notes that the importance of CSOs to any reform in a democracy cannot be underestimated. While their participation thus far, in the security governance in Nigeria has been limited, they are increasingly being recognized as important actors in the changing political environment. These civil society including professionals, advocacy 
groups, research and policy think-tanks, religious groups, and the media can agitate for change and articulate reform agendas. Despite the challenges commonly attributed to most African civil society organizations, they can and should act as watchdogs and provide technical input. They can provide knowledge, training, research, initiate dialogue between the security establishments and the public. This way, they contribute to shaping policy formulation, policy environment and policy framework. Civil society organizations are therefore, indispensible partners in the attempt at democratizing the Nigerian security sector. Also, the emergence of a new political party in the 2015 elections is widely seen as a good omen for Nigeria in spite of the manifold security challenges facing the country. Such change could offer numerous opportunities for all stakeholders involved in the democratization process In this light, Nigeria must take advantage of the somewhat favourable domestic and external environment to re-engage all stakeholders to confront national security challenges. Identifying the need for reform is not as important as being guided by the norms and standard practices that would yield the desired result whether in the short or long term. It is, therefore anticipated that all relevant actors would seize the opportunity to promote human security which should further complement state security, enhance human rights and strengthen human development in Nigeria (Commission on Human Security, 2003). ${ }^{25}$

Beyond the aforementioned however, the rule of law, a truly democratic constitution and viable institutions are key to effective democratic governance. Over-centralization of control of the armed forces and various national security agencies in the hands of the executive may continue to hinder the strengthening of the country's democracy. This is crucial for institution building to restore legitimacy and trust, through accountability and transparency. Independence is also important for the legislature to carry out its oversight functions. Also, the creation of a professional ethos within the security services that is consistent with the dictates of modern democracy must be developed, implemented and monitored to ensure that the benefits of democratization is not lost on the overall security well-being of the country. Lastly, given the role that Nigeria continues to play in the sub-region, intervening to restore and promote democracy and economic development, an enhanced national security sector will further legitimize its actions and possibly reduce the incidences of conflicts and improve conflict management approaches in West Africa.

\section{Conclusion}

A sustainable, functional democratic system remains pivotal to ensuring effective security management in Nigeria. From a policy perspective, the country seems to be on the right path as it continues to modify its security structures in line with global best practices and standards. The idea of human security continues to permeate the conception and discourse on national security due largely to the increasingly visible roles played by new actors such as the civil society organizations in the security sector. Despite these gains, numerous challenges persist ranging from poor or inhumane implementation of security policies, ingrained military culture, entrenched corruption, lack of political will, fractured ethnic 
relations, institutional weakness, and lack of trust between the government and the citizens, among others. Consequently, the process of democratic consolidation in Nigeria has been slow and largely unaccountable.

To build a resilient democratic system and a human-centered security architecture that is mutually reinforcing, institutions in Nigeria must be strengthened to reflect the values and ethos of democracy. The three arms of the government - executive, legislature and the judiciary must be purged of every vestige of corruption while simultaneously putting in place a mechanism for the re-orientation of essential national values. Also, there is the need for the CSOs to play a greater role in the management of Nigeria's security by emphasizing the importance of security to democratic consolidation. Finally, attempts must be made to deepen the country's democracy by ensuring inclusive policies that promote a sense of belonging and patriotism.

\section{Endnotes}

${ }^{1}$ Freedom House. (2015). Freedom in the World 2015: Discarding Democracy: A Return to the Iron Fist. Retrieved June 2016, from www.freedomhouse.org/report/freedom-world/freedom-world-2015; Freedom House. (2014). Freedom in the World 2014: Democratic Leadership Gap. Retrieved June 2016, from www.freedomhouse.org/ report/freedom-world/freedom-world-2014; and Freedom House. (2013). Freedom in the World 2013: Democratic Breakthroughs in the Balance. Retrieved June 2016, from www.freedomhouse.org/report/freedom-world/ freedom-world-2013

${ }^{2}$ Yagboyaju, Dhikru Adewale. (2013). Democratic consolidation, fiscal responsibility and national development: An appraisal of the fourth republic. African Journal of Political Science and International Relations, 101.

${ }^{3}$ Asiwaju, A. I. (2000). Sharing best practice experiences in democracy-building in non-french speaking African states. Draft paper presented at the 4th International Conference on New and Emerging Democracies, Cotonou, Benin Republic, December 4-6.

${ }^{4}$ UNDP, Human Development Report. (1994). Oxford: Oxford University Press.

5 ‘Human Security Now'. (2003). Commission on Human Security, New York.

${ }^{6}$ Chalmers, Malcolm. (2000). Security sector reform in developing countries: An EU perspective. London/ Ebenhausen: Safer World and Conflict Prevention Network, p. 6, Retrieved April 2015, from www.saferworld.co.uk/ publications/Secform.html

${ }^{7}$ OECD. (2004). Security system reform and governance: Policy and good practice. AAC Reference Document. Paris: OECD, p. 16.

${ }^{8}$ Ball, N., \& Fayemi, K. (Ed.). (2004). Security sector governance in Africa: A handbook. Funmi Olonisakin., \& Rocklyn Williams Centre for Democracy and Development.

${ }^{9}$ Hutchful, Ebo. (2003). Pulling back from the brink: Ghana's experience. In Cawthra, G. and Luckham, R. (Ed.). Governing insecurity: Democractic control of military and security establishment in transitional democracies. UK, Zed Books Ltd.

${ }^{10}$ Nicole, B., Tsjeard Bouta., \& Luc van de Goor. (2003). Enhancing democratic governance of the security sector: An institutional assessment framework. The Clingendael Institute for the Netherlands Ministry of Foreign Affairs, 30. 
${ }^{11}$ Hendrickson, Dylan, \& Karkoszka, Andrzej. (2005). Security sector reform and donor policies in security sector reform and post-conflict peacebuilding. Edited by Albrecht Schnabel and Hans-Georg Ehrhart. Tokto, Japan: United Nations University Press.

${ }^{12}$ Fayemi, J. K., \& Olonisakin, F. (2008). Nigeria. In A. Bryden, B. N' Diaye., \& F. Olonisakin (Eds.). Challenges of security sector governance in West Africa, (243-267). Geneva: Geneva Centre for the Democratic Control of Armed Forces.

${ }^{13}$ Global Terrorism Index. (2015). Measuring and understanding the impact of terrorism. Institute for Economics and Peace, pp.13-14.

${ }^{14}$ Ibid. p.15.

${ }^{15}$ Fragile States Index. (2015). The fund for peace, Washington D. C., p.12.

16 UNHCR Regional Update No. 23: Nigeria Situation. (2016, April 1-30). Retrieved 23 May, 2016, from http:// reliefweb.int/report/nigeria/nigeria-situation-unhcr-regional-update-no-23-1-30-april-2016

${ }^{17}$ Schwab Klaus. (Ed.). Insight report. The Global Competitiveness Report 2015-2016. 2015 World Economic Forum, p.9.

${ }^{18}$ Doing Business. (2015). Going beyond efficiency. A World Bank Flagship Report, 12th (ed.) p.4. and Doing business. (2016). Measuring regulatory quality and efficiency. A World Bank Group Flagship Report. (13 ${ }^{\text {th }}$ ed.). p.5. ${ }^{19}$ The destruction of Odi and rape in Choba. (December 22, 1999). Nigeria- Human Rights Watch World Report 2000. https://www.hrw.org/legacy/press/1999/dec/nibg1299.htm;1 and Nigeria: Soldiers massacre civilians in revenge attack in Benue state. Human Rights Watch, October 25, 2001. Retrieved June 14, 2015, from https://www. hrw.org/news/2001/10/25/nigeria-soldiers-massacre-civilians-revenge-attack-benue-state2

${ }^{20}$ Jonathan unveils new national security strategy. (2015, February 5). Premium Times.

${ }^{21}$ Human Development Report. (1994). Op cit.

${ }^{22}$ French white paper on defence and national security. Nicholas Sarkozi. (2007). Odile Jacob Publishing.

${ }^{23}$ Jonathan Unveils New National Security Strategy. Dasuki, Sambo, National Security Adviser. Op cit.

${ }^{24}$ Eniola Akinkuotu. (2014, July). Terrorism: Jonathan's \$1bn loan request dubious, says APC. Retrieved 20 April 2015, from www.punchng.com/news/terrorism-jonathans-ibn-loan-request-dubious-says-apc/

${ }^{25}$ Commission on human security. (2003). Security Now, New York. Retrieved 26 April 2015, from http://www. humansecurity-chs.org/finalreport.pdf 